\title{
Effects of addition of somatic cells to caprine milk on cheese quality
}

\author{
D. Sánchez-Macías ${ }^{\mathrm{a}}$, A. Morales-delaNuez ${ }^{\text {b }}$, A. Torres ${ }^{\text {c }}$, L.E. Hernández-Castellano ${ }^{\text {b }}$, R. Jiménez-Flores ${ }^{\text {d }}$, \\ N. Castro ${ }^{\mathrm{b}}$, A. Argüello ${ }^{\mathrm{b}, *}$ \\ a Agricultural and Livestock Engineering Faculty, Universidad Estatal del Sur de Manabí, Jipijapa 130650, Manabí, Ecuador \\ ${ }^{\mathrm{b}}$ Department of Animal Science, Universidad de Las Palmas de Gran Canaria, Arucas 35413, Spain

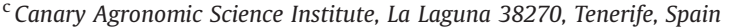 \\ ${ }^{\mathrm{d}}$ Dairy Products Technology Center, California Polytechnic State University, CA, USA
}

\begin{abstract}
A B S T R A C T
Milk quality criteria and limits for somatic cell count (SCC) established in many countries make it difficult to maintain SCC of bulk tank goat milk below the threshold, due to non infection factors linked to goat physiology. The aim of this study was to objectively verify the effects of SCC on fresh caprine milk cheese. Somatic cells were recovered from pooled healthy goat milk, and added to low SCC raw or pasteurised goat milk. Miniature cheeses were made and evaluated after 1 and $7 \mathrm{~d}$. Somatic cells had a major effect on lipolysis, increasing free fatty acids regardless of whether milk was raw or pasteurised. The effect of somatic cells on proteolysis was specific for caseins and the effects were different if cheeses are made from raw or pasteurised milk. It is concluded that somatic cells themselves in caprine milk can directly affect some cheese parameters.
\end{abstract}

\section{Introduction}

Currently, there is an increased demand for caprine and diverse products. Ribeiro and Ribeiro (2010) and Silakinove, Leitner, Merin, and Prosser (2010) reviewed the healthy properties of caprine milk and products. According to Food and Agriculture Organization of the United Nations (FAOSTAT, 2012), the worldwide dairy goat population reached 191 million in 2010, and caprine milk produc tion surpassed 16.7 million tons, representing significant increases of 25 and 31\%, respectively, compared with a decade ago. The populations of dairy goats in the USA and the European Union in 2010 were 356,000 and 7,732,631, respectively.

Milk quality criteria are part of payment systems for milk, thereby ensuring good quality finished products (Raynal Ljutovac, Gaborit, \& Lauret, 2005). In the USA, the legal maximum for SCC (somatic cell count) established by the Food and Drug Administra tion is 750,000 cells $\mathrm{mL}^{-1}$ and $1,000,000$ cells $\mathrm{mL}^{-1}$, respectively for bovine and caprine milk. In the European Union (Directive 92/ 46ECC Council, 1992), the legal limit for bovine milk is 400,000 cells $\mathrm{mL}^{-1}$ and there is no legal limit for caprine and ovine milk. Some authors (Paape et al., 2007; Raynal Ljutovac, Pirisi, de Crémoux, \& Gonzalo, 2007) have reported that North American goat producers have difficulty maintaining bulk tank goat milk SCC below the threshold limit due to non infectious factors, such as breed, parity, stage of lactation, oestrus, diurnal, monthly and seasonal variations (Fernández, Rodriguez Alcala, Abilleira, de la Fuente, \& Fontecha, 2009; Haenlein \& Hinckley, 1995; Paape, Poutrel, Contreras, Marco, \& Capuco, 2001) that have major impact on counts in caprine milk; this should be taken into account when the European Union establishes limits for SCC in caprine milk.

Numerous studies have shown that increased SCC in bovine milk results in decreased milk production and affects milk composition, which causes a reduction in the ability to produce cheese and decreases the shelf life of consumer milk (Erdem, Atasever, \& Kul, 2010; Ma, Barbano, \& Santos, 2003; Politis \& Ng Kwai Hang, 1988). The main component of the economic loss associated with SCC is the reduced milk production in cows with mastitis (Huijps, Lam, \& Hogeveen, 2008). Raynal Ljutovac et al. (2005) concluded that somatic cells, although they are an indicator of the hygienic quality of goat milk, do not seem to necessarily impair cheese making. However, Raynal Ljutovac et al. (2007) intensively reviewed analytical, sanitary, productive and technological effects of somatic cells on caprine milk and cheese, and controversies among the conclusions of the studies were found, probably due to the different variables, such as the variety of cheese making or using different animals in each experimental group.

Despite these differences, it is not clear what the effects of somatic cells are on milk properties, cheese quality, lipolysis and 
proteolysis. Marino, Considine, Sevi, McSweeney, and Kelly (2005) recovered somatic cells from mastitic bovine milk and added them to good quality milk, then evaluated their contribution to proteolysis during Cheddar cheese ripening; these authors concluded that proteolytic enzymes of somatic cells from milk contributed directly to proteolysis in milk and cheese. Caroprese et al. (2007) studied the effect of macrophages on proteolysis and plasmin activity in bulk ovine milk. Somatic cells contain a range of lysosomal enzymes, such as cathepsin B, cathepsin D, cathepsin G and elastase (Le Roux, Laurent, \& Moussaoui, 2003), many of which pass into the milk, where they cause increased proteolysis and lipolysis (Albenzio et al., 2005; Le Roux, Colin, \& Laurent, 1995). Many somatic cell enzymes have been found or measured in frac tions of milk other than the cells themselves, suggesting that leakage or secretion of enzymes occurs, or that the cells lyse and release their intracellular enzymes (Kelly \& Fox, 2006). Moreover, increasing SCC is usually accompanied by imbalances in other parameters in milk, so it is very difficult to determine if somatic cells are directly responsible for changes in milk and cheese.

Milk pasteurisation is commonly practiced before making cheese. This heat treatment inactivates microorganisms, activatesinactivates indigenous milk pro enzymes and enzymes, partially denatures whey proteins, and modifies starter bacteria activity. It also concomitantly reduces fermentation and degradation reactions (Buchin et al., 1998; Grappin \& Beuvier, 1997). Marino et al. (2005) reported that proteolysis during ripening of cheese increased with addition of somatic cells, although this effect was reduced by pas teurisation after cell addition. A relationship between proteolysis in milk and SCC was described by Hachana and Kraiem (2009).

In the Canary Islands, most caprine milk cheese is made with raw milk, using traditional methods (Fresno et al., 2008). The islands have an exceptional sanitary situation, due to being offi cially free of caprine and ovine brucellosis. This fact allows approximately 500 artisan producers to sell raw milk cheese after less than 60 days of ripening. Overall, few studies about the direct effect of somatic cells from healthy animals on cheese ripening have been reported in the literature, and no objective study has been reported about the contribution of somatic cells to cheese made following a simple rennet cheese making process using raw caprine milk. The aims of this study were to objectively verify the effects of somatic cells on chemical composition, proteolysis and lipolysis profile of fresh cheese made with raw or pasteurised caprine milk.

\section{Material and methods}

\subsection{Recovery of somatic cells}

Somatic cells were recovered by centrifugation $(280 \times \mathrm{g}$, $20 \mathrm{~min}$, $4{ }^{\circ} \mathrm{C}$ ) (Beckman, J2 CI Centrifuge, Beckman Coulter Inc., FL, USA)

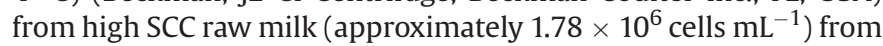
two healthy Majorera breed goats from the Animal Science Unit of Universidad de Las Palmas de Gran Canaria. The resulting pellet was resuspended in phosphate buffered saline at $\mathrm{pH} 6.8$, as described by Verdi and Barbano (1991), until a pool with approximately $2.1 \times 10^{7} \mathrm{SCC} \mathrm{mL} \mathrm{mb}^{-1}$ was obtained. The SCC of this stock preparation, before and after dilution in phosphate buffered saline (PBS), was determined using a DCC Device counter (DCC, DeLaval International AB, Tumba, Sweden). The type of somatic cell in the pool was not specifically determined, but is likely that the somatic cell pop ulation in caprine milk is dominated by polymorphonuclear neutrophils (45-74\%), followed by macrophages (15-41\%) and lymphocytes (9-20\%) (Dulin, Paape, Schultze, \& Weinland, 1983). This process was repeated every day before making cheese from the same goats.

\subsection{Cheese production}

Miniature cheese systems have been proposed as the best alternative to pilot plant experiments, being closer to cheese than any other model proposed to date; moreover, they can be prepared under controlled conditions and are more economical, reproducible and easier to obtain (Shakeel Ur Rehman, Fox, McSweeney, Madkor, \& Farkye, 2001).

\subsubsection{Cheese formulation}

Raw goat milk with low SCC (approximately $2 \times 10^{5} \mathrm{SCC} \mathrm{mL}^{-1}$ ) was used to make the miniature cheeses. Over $10 \mathrm{~L}$ of milk was obtained from four goats from a healthy experimental herd of Majorera dairy goat breed. The four batches of experimental cheeses were produced using six different experimental treatments (three levels of SCC and pasteurisation or non pasteurisation). Each day the raw caprine milk was separated into two groups: raw milk or pasteurised milk (63 ${ }^{\circ} \mathrm{C}$ for $30 \mathrm{~min}$ ). Both groups were then divided into three subgroups with different levels of somatic cells added: low SCC milk (without somatic cells added), medium SCC milk (mean value approximately $1 \times 10^{6} \mathrm{~mL}^{-1}$ ), and high SCC milk (mean value approximately $2.5 \times 10^{6} \mathrm{~mL}^{-1}$ ). Somatic cells were added after pasteurisation of milk. The finished cheeses were ripened for 1 and $7 \mathrm{~d}$ in duplicate, resulting in a total of 96 cheese samples ( 4 batches $\times$ raw or pasteurised milk $\times 3$ level of SCC $\times 2$ ripening times $\times$ duplicate).

\subsubsection{Manufacture of miniature cheese}

Cheeses were made with six different milk treatments: raw milk low SCC (RL) cheese, raw milk medium SCC milk (RM) cheese, raw milk high SCC (RH) cheese, pasteurised milk low SCC (PL) cheese, pasteurised milk medium SCC (PM) cheese, and pasteurised milk high SCC (PH) cheese. Milk was salted with $4 \mathrm{~g} \mathrm{NaCl}$ for $100 \mathrm{~mL}$ milk. The same procedure was used to make each type of miniature cheese: $40 \mathrm{~mL}$ of salted milk was poured into four $50 \mathrm{~mL}$ centrifuge tubes, which were then placed in a water bath at $32{ }^{\circ} \mathrm{C}$. Commercial animal rennet (Marshall rennet powder, Rhône Poulenc Texel, Dangé Saint Romain, France), comprising 50\% pepsin and 50\% chymosin, was used. No starter cultures were added. Curd was cut 45 min after rennet addition with a stainless steel spatula and allowed to stand for additional $5 \mathrm{~min}$. The curds were then centrifuged at $3400 \times g$ for $20 \mathrm{~min}$ and the whey was discarded. The non packaged cheeses were divided randomly into two groups and allowed to ripen 1 or $7 \mathrm{~d}$ at $10-12{ }^{\circ} \mathrm{C}$ and $75-80 \%$ relative humidity.

\subsection{Gross composition, $\mathrm{pH}$ and colour measurement of cheese}

Cheese pH was measured was determined using a Crisson 507 $\mathrm{pH}$ meter at 3 internal (in the cheese centre) locations for each cheese. After that, cheese samples were cut into small pieces, weighed and freeze dried. The difference in weight before and after the freeze drying was used to calculate the percentage moisture content. The rest of the analysis was performed with the resultant dried matter. Soxhlet extraction was performed to quantify the fat content in dry basis using a Büchi 810 Soxhlet fat extraction apparatus (Büchi Labortechnik, Flawil, Switzerland). Protein content was determined in duplicate as $\% N \times 6.38$ using a LECO CNS 2000 nitrogen analyser (Leco Corporation, St. Joseph, MI, USA).

\subsection{Extraction of proteins and electrophoretic analysis}

All chemical reagents were of analytical grade from Panreac (Barcelona, Spain), Merck (Darmstadt, Germany), and Bio Rad Laboratories (Hercules, CA, USA). Water soluble proteins were 
extracted from the cheeses after 1 and $7 \mathrm{~d}$ of ripening using the method described by Tunick, Malin, Smith, and Hilsinger (1995) as modified by Sánchez Macías et al. (2011).

Lyophilised samples were prepared, separated by SDS PAGE (Laemmli, 1970), and stained as described by Sánchez Macías et al. (2011). Images of stained gels were captured with a Bio Rad imaging device (Gel Doc EQ; Bio Rad Laboratories), and bands were quantified using Quantity One Quantitation Software (Bio Rad Laboratories). Densitometry analysis of the gels was performed using lane based background subtraction followed by measure ment of the bands by the area under the intensity profile curve, and the values were then used for statistical analysis. Each sample was analysed on duplicate gels. Individual protein species from cheese samples were identified by comparing their relative mobilities with those of standard proteins (Bio Rad Laboratories) from a previous SDS PAGE gel.

\subsection{Total free fatty acids (copper soap method)}

The total free fatty acid (FFA) content was determined using the copper soap method (Melilli et al., 2004; Shipe, Senyk, \& Fountain, 1980), modified for cheese analysis as described by Sánchez Macías et al. (2011). The final results were expressed as milligrams of FFA per $100 \mathrm{~g}$ of dry matter (DM) of cheese and were also converted to milligrams of FFA per $g$ of fat in cheese.

\subsection{Statistical analysis}

Statistical analyses were performed using the SAS program package (Version 9.00, SAS Institute Inc., Cary, NC, USA). A PROC MIXED procedure (analysis of variance with repeated measures) was used to evaluate the effect of different SCC level and ripening time on the chemical composition, $\mathrm{pH}$, lipolysis level, and level of primary proteolysis of the raw or pasteurised goat milk cheeses. Significantly different means were identified using the Tukey's test.

\section{Results and discussion}

\subsection{Gross chemical cheese analysis and $\mathrm{pH}$ values}

The gross chemical composition and $\mathrm{pH}$ of cheeses after 1 and $7 \mathrm{~d}$ of ripening are shown in Table 1 . At day 1 of ripening, the moisture was higher in control pasteurised milk cheese than its counterpart made with raw caprine milk, though no differences were found between $\mathrm{RH}$ and $\mathrm{PH}$ cheeses. These data concur with the findings of Pearse, Linklater, Hall, and MacKinlay (1985), who reported an adverse effect of heat treatment on syneresis of rennet induced milk gels using model systems. This effect on syneresis is probably due to the presence of denatured whey protein on the surface of the micelles, which retard aggregation and fusion of the rennet treated micelles (Rynne, Beresford, Kelly, \& Guinee, 2004). Henry, Mollé, Morgan, Fauquant, and Bouhallab (2002) reported that more water is bound in cheese when $\beta$ lactoglobulin- $\kappa$ casein complexes are formed after pasteurisation of milk. Moisture content decreased after $7 \mathrm{~d}$ of ripening in all cheeses because of surface water evaporation, and no differences were found between cheeses. Marino et al. (2005) suggested in a similar study that somatic cells themselves may contribute to the increase in moisture content in Cheddar type cheeses ripened for 15 days, and they proposed that the inclusion of cells may physically interfere with the process of curd syneresis of this type of cheese. Fat percentage in DM was within the ranges required by Spanish regulation for full fat (60-45\% fat in DM) cheese designation, and very similar to those found by Sánchez Macías et al. (2010) in cheese made from milk from the same breed.

Protein content on a DM basis was similar among the different cheeses in the study; however, an increase of this parameter was found after $7 \mathrm{~d}$ of ripening. van Vliet and Walstra (1994) reported that about $90 \%$ of the water present in milk gels is mechanically enclosed between the casein aggregates, which determines the ease of removal of water from the gel. The increased protein content measured on a DM basis can be explained due to the more possible water that is released and available after $7 \mathrm{~d}$ of ripening, which can be extracted from cheeses after the casein network is broken down due to proteolysis. As cheeses were not packaged, some available water evaporated from their surfaces. Cheese $\mathrm{pH}$ was approximately 6.6 at $1 \mathrm{~d}$ of ripening, similar to the typical values reported for Majorera caprine milk cheese (Álvarez et al., 2007; Sánchez Macías et al., 2010). During the first week of ripening, $\mathrm{pH}$ values decreased in all cheese groups, though PL cheese had a significantly higher value than the others. Pirisi et al. (2000) and Vianna, Mazal, Santos, Bolini, and Gigante (2008) re ported that higher milk SCC resulted in increased $\mathrm{pH}$ in cheese, while other authors (Jaeggi, Govindasamy Lucey, Berger, \& Johnson, 2003) did not observe significant variations, possibly due to other changes in the milk that accompanied the increasing SCC. Marino et al. (2005), on adding somatic cells from mastitic milk to control milk, did not find significant differences of $\mathrm{pH}$ in cheeses. In

Table 1

Chemical composition and pH of cheese made with (raw or pasteurised) caprine milk at three levels of SCC (somatic cell count) after 1 and $7 \mathrm{~d}$ of ripening. ${ }^{\mathrm{a}}$

\begin{tabular}{|c|c|c|c|c|c|c|c|c|}
\hline \multirow[t]{2}{*}{ Parameter $^{\mathrm{b}}$} & \multirow[t]{2}{*}{ Time } & \multicolumn{7}{|c|}{ Treatment $^{\mathrm{c}}$} \\
\hline & & RL & RM & $\mathrm{RH}$ & PL & PM & $\mathrm{PH}$ & SEM \\
\hline \multirow[t]{3}{*}{ Moisture (\%) } & 1 & $48.86^{\mathrm{b}}$ & $49.65^{\mathrm{bA}}$ & $51.98^{\mathrm{abA}}$ & $55.27^{\mathrm{aA}}$ & $55.02^{\mathrm{aA}}$ & $53.37^{\mathrm{abA}}$ & 0.57 \\
\hline & 7 & 43.75 & $43.72^{\mathrm{B}}$ & $44.18^{\mathrm{B}}$ & $43.43^{\mathrm{B}}$ & $43.83^{\mathrm{B}}$ & $44.32^{\mathrm{B}}$ & 0.61 \\
\hline & SEM & 2.61 & 2.70 & 2.90 & 3.41 & 3.33 & 3.07 & \\
\hline \multirow[t]{3}{*}{ Fat in DM (\%) } & 1 & 44.19 & 45.82 & 46.58 & 45.59 & 47.05 & 46.47 & 0.42 \\
\hline & 7 & 45.44 & 46.46 & 44.60 & 46.89 & 47.57 & 48.74 & 0.35 \\
\hline & SEM & 0.21 & 0.17 & 0.37 & 0.40 & 0.12 & 0.39 & \\
\hline \multirow[t]{3}{*}{ Protein in DM (\%) } & 1 & $35.53^{B}$ & $36.58^{\mathrm{B}}$ & $36.30^{\mathrm{B}}$ & $35.50^{\mathrm{B}}$ & $35.34^{\mathrm{B}}$ & $36.72^{\mathrm{B}}$ & 0.36 \\
\hline & 7 & $38.81^{\mathrm{A}}$ & $40.13^{\mathrm{A}}$ & $39.61^{\mathrm{A}}$ & $38.05^{\mathrm{A}}$ & $38.21^{\mathrm{A}}$ & $39.48^{\mathrm{A}}$ & 0.43 \\
\hline & SEM & 0.32 & 0.21 & 0.47 & 0.11 & 0.19 & 0.28 & \\
\hline \multirow[t]{3}{*}{$\mathrm{pH}$} & 1 & $6.56^{\mathrm{A}}$ & $6.61^{\mathrm{A}}$ & $6.62^{\mathrm{A}}$ & $6.60^{\mathrm{A}}$ & $6.61^{\mathrm{A}}$ & $6.60^{\mathrm{A}}$ & 0.01 \\
\hline & 7 & $5.67^{\mathrm{abB}}$ & $5.68^{\mathrm{abB}}$ & $5.53^{\mathrm{aB}}$ & $6.23^{\mathrm{cB}}$ & $5.83^{\mathrm{bB}}$ & $5.72^{\mathrm{bB}}$ & 0.08 \\
\hline & SEM & 0.12 & 0.12 & 0.15 & 0.06 & 0.12 & 0.13 & \\
\hline
\end{tabular}

${ }^{a}$ Values are means; values with different lower case superscript letters within a row and values with different upper case superscript letters within a column differ $(P<0.05)$ for the parameter; SEM, standard error of the mean.

b DM, dry matter.

c Treatments: RL, raw goat milk with low SCC; RM, raw goat milk with medium SCC; RH, raw goat milk with high SCC; PL, pasteurised goat milk with low SCC; PM, pasteurised goat milk with medium SCC; PH, pasteurised goat milk with high SCC. 
this study, somatic cells from healthy goats were used, and cheese $\mathrm{pH}$ decreased as somatic cells were added to the caprine milk.

\subsection{Lipolysis during cheese ripening}

Mean levels of FFA are summarised in Table 2. The indigenous lipoprotein lipase (LPL) hydrolyses the 1,3 position in mono, di , and triglycerides to give free fatty acids. Large proportions of caprine milk LPL are bound to cream, and not to caseins, unlike in bovine milk, which could explain why lipolysis in milk is well correlated with milk LPL activity in this species (Chilliard, Selselet Attou, Bas, \& Morand Ferh, 1984). FFA levels did not differ signifi cantly among the cheeses after $1 \mathrm{~d}$ of ripening; however, slight increases in FFA content were found as SCC increased in cheese milk.

Quantitative analysis of the total FFA content showed a general increase in all cheeses after $7 \mathrm{~d}$ of ripening, and the levels were higher as SCC increased in milk. Moreover, raw caprine milk cheese had higher levels of FFA than pasteurised caprine milk cheese, for both low SCC samples. Other authors have found lower levels of FFA in cheese on comparing pasteurised and raw milk cheeses: $38 \%$ and 50\% lower FFA content in Manchego Cheese (Gaya, Medina, Rodriguez Marin, \& Nuñez, 1990) and Cheddar cheese (McSweeney, Fox, Lucey, Jordan, \& Cogan, 1993), respec tively. Morgan and Gaborit (2001) reported that the processing of the caprine milk (cheese, yoghurt), physical treatment, and cold storage increased the lipolysis level in the milk, whereas pasteur isation decreased the level of lipolysis. Medium and high SCC milk cheeses had similar FFA content for both raw and pasteurised milk. Chen, Wang, Van Kessel, Ren, and Zeng (2010) reported that SCC in pasteurised goat milk cheese did not significantly affect FFA content, and similar results were obtained by Jaeggi et al. (2003) for hard ewe milk cheese. In both cases, cheese milk was collected from animals grouped according to SCC and, thus, not only somatic cells themselves were involved in lipolysis in cheese, but other changes in milk. Moreover, in the present study, somatic cells were added to the milk after pasteurisation, which means that somatic cell enzymes were not affected by heating, and lipolysis clearly depended on somatic cells. Lipolysis only occurs when the membrane of the fat globules is broken, and the fat is accessible to the enzyme. Azzara and Dimick (1985) found that macrophages from mastitic bovine milk secreted lipolytic enzymes which may bind to the fat globule membrane and damage it, exposing the fat to degradation by LPL.

\section{Table 2}

Total free fatty acid (FFA) levels in cheese made with (raw or pasteurised) caprine milk at three levels of somatic cell count (SSC) after 1 and $7 \mathrm{~d}$ of ripening. ${ }^{\text {a }}$

\begin{tabular}{|c|c|c|c|c|c|c|c|}
\hline \multirow[t]{2}{*}{ Time } & \multicolumn{7}{|c|}{ Treatment $^{\mathrm{b}}$} \\
\hline & RL & RM & $\mathrm{RH}$ & PL & PM & $\mathrm{PH}$ & SEM \\
\hline \multicolumn{8}{|c|}{ Total FFA (mg) per $100 \mathrm{~g}$ of $D^{\mathrm{c}}$} \\
\hline 1 & $52.92^{\mathrm{A}}$ & $54.21^{\mathrm{A}}$ & $60.96^{\mathrm{A}}$ & $48.59^{\mathrm{A}}$ & $56.26^{\mathrm{A}}$ & $63.75^{\mathrm{A}}$ & 3.14 \\
\hline 7 & $243.5^{\mathrm{cB}}$ & $441.01^{\mathrm{bB}}$ & $641.58^{\mathrm{aB}}$ & $113.94^{\mathrm{dB}}$ & $468.10^{\mathrm{bB}}$ & $581.34^{\mathrm{aB}}$ & 35.10 \\
\hline SEM & 33.09 & 55.19 & 86.11 & 11.60 & 59.52 & 72.49 & \\
\hline \multicolumn{8}{|c|}{ Total FFA (mg) per $g$ of fat in cheese } \\
\hline 1 & $1.15^{\mathrm{A}}$ & $1.17^{\mathrm{A}}$ & $1.31^{\mathrm{A}}$ & $1.04^{\mathrm{A}}$ & $1.20^{\mathrm{A}}$ & $1.36^{\mathrm{A}}$ & 0.07 \\
\hline 7 & $5.22^{\mathrm{cB}}$ & $9.41^{\mathrm{bB}}$ & $13.81^{\mathrm{aB}}$ & $2.47^{\mathrm{dB}}$ & $10.14^{\mathrm{bB}}$ & $12.49^{\mathrm{aB}}$ & 0.64 \\
\hline SEM & 0.70 & 1.17 & 1.83 & 0.24 & 1.21 & 1.47 & \\
\hline
\end{tabular}

a Values are means; values with different lower case superscript letters within a row and values with different upper case superscript letters within a column differ $(P<0.05)$ for the parameter; SEM, standard error of the mean.

b Treatments: RL, raw goat milk with low SCC; RM, raw goat milk with medium SCC; RH, raw goat milk with high SCC; PL, pasteurised goat milk with low SCC; PM, pasteurised goat milk with medium SCC; PH, pasteurised goat milk with high SCC. c DM, dry matter.
In cheese, lipolysis results in the formation of FFA that may contribute to cheese flavour and also serve as substrates for further reactions, with the consequence of producing highly flavoured catabolic end products (Collins, McSweeney, \& Wilkinson, 2003). Jaubert, Bodin, and Jaubert (1996) observed a positive correlation between lipolysis and SCC in goat milk, and a more intense caprine flavour with increasing SCC was found in caprine milk. Sensory studies are needed to evaluate if somatic cells themselves are able to affect the sensory characteristics of cheese made from caprine milk.

\subsection{Protein profile and proteolysis during cheese ripening}

A densitometer derived protein distribution analysis is sum marised in Table 3. Primary proteolysis essentially measures the extent of breakdown of caseins, which occurs mainly as a result of the action of residual coagulant, plasmin (PL), and somatic cell proteinases. However, microorganisms are also active in the hydrolysis of caseins (Fox, 1993; Fox \& McSweeney, 1996). Harmon (1994) and Moslehishad and Ezzatpanah (2010) described that the increasing SCC of milk affects casein micelle microstructure and properties due to hydrolysis of casein. Due to the increasing proteolytic activity of enzymes such as PL, neutral, and acidic proteases, therefore, casein could be more susceptible to hydrolysis.

During ripening, $\beta \mathrm{CN}$ bands had the highest intensity values, followed by $\alpha_{\mathrm{S} 2} \mathrm{CN}$ and $\alpha_{\mathrm{S} 1} \mathrm{CN}$. Caprine milk contains relatively little $\alpha_{\mathrm{S} 1} \mathrm{CN}$, and $\beta \mathrm{CN}$ is the major protein (Tziboula Clarke, 2003). Quantitative analysis showed a general reduction in casein fractions as ripening progressed, and hydrolysis was higher for $\beta \mathrm{CN}(26-43 \%$ reduction), than for para $\kappa \mathrm{CN}(23-37 \%), \alpha_{\mathrm{S} 2} \mathrm{CN}(20-30 \%)$, and $\alpha_{\mathrm{S} 1}$ CN (14-25\%). Pasteurised caprine milk cheese had higher levels of caseins compared with raw caprine milk cheese when no somatic cells were added. On the other hand, different patterns of casein breakdown were found as SCC was increased in raw or pasteurised goat milk cheeses.

Regarding $\alpha_{\mathrm{S} 2} \mathrm{CN}$, this was degraded faster in RM and RH cheese than in RL cheese, when expressed in absolute values. However, when expressed as percentage breakdown from 1 to $7 \mathrm{~d}$, a faster breakdown of this casein was observed in RM and RH compared to RL cheese. On the other hand, hydrolysis of $\alpha_{\mathrm{S} 2} \mathrm{CN}$ was accelerated in pasteurised caprine milk cheese when somatic cells were added.

The level of $\alpha_{\mathrm{S} 1} \mathrm{CN}$ in cheese was not affected by heat treatment or somatic cell addition; however a lower content was found after $7 \mathrm{~d}$ of ripening in all cheese types. Marino et al. (2005) found that adding somatic cells from mastitic milk to cow milk resulted in faster hydrolysis of $\alpha_{\mathrm{S} 1} \mathrm{CN}$ in cheese at $15 \mathrm{~d}$ of ripening than in control cheese, indicating accelerated proteolysis of this casein.

In this study, $\beta$ CN content was similar in all cheese groups after $1 \mathrm{~d}$ of ripening, and a significant reduction of this casein was found at $7 \mathrm{~d}$ of ripening. Proteolysis of $\beta \mathrm{CN}$ was similar in RL and PL. There were no differences in $\beta \mathrm{CN}$ breakdown between raw milk cheeses. In contrast, the rate of $\beta \mathrm{CN}$ breakdown increased with increasing SCC in pasteurised milk cheese. It is notable that, in pasteurised milk cheeses, the breakdown of $\beta \mathrm{CN}$ was higher than its respective cheeses made with raw caprine milk. When isolated and lysed macrophages from bulk ewe milk were incubated with sodium caseinate, changes in percentage composition of intact casein were observed: $\beta \mathrm{CN}$ did not undergo appreciable hydro lysis, unlike $\alpha$ CN (about 20\%) (Caroprese et al., 2007).

Plasmin (PL), the main indigenous proteolytic enzyme in milk, is associated with the casein micelles, and milk contains the entire PL system: PL, plasminogen (PG), PL inhibitors, PG activators (PAs), and inhibitors of PAs. PAs have been associated with somatic cells fraction in goat milk (Politis et al., 1994). PL acts mainly on $\beta$ casein, which constitutes approximately $60 \%$ of the total casein in caprine 
Table 3

Densitometric values (intensity $\times$ mm) of SDS-PAGE protein bands in cheese made with caprine milk (raw or pasteurised) at three levels of SCC (somatic cell count) after 1 and $7 \mathrm{~d}$ of ripening.

\begin{tabular}{|c|c|c|c|c|c|c|c|c|}
\hline \multirow[t]{2}{*}{ Parameter $^{\mathrm{b}}$} & \multirow[t]{2}{*}{ Time } & \multicolumn{7}{|l|}{ Treatment $^{\mathrm{c}}$} \\
\hline & & $\mathrm{RL}$ & RM & RH & PL & PM & $\mathrm{PH}$ & SEM \\
\hline \multirow[t]{3}{*}{$\alpha_{\mathrm{S} 2}-\mathrm{CN}$} & 1 & $846.28^{\mathrm{cA}}$ & $1021.21^{\mathrm{bA}}$ & $1032.35^{\mathrm{abA}}$ & $1100.04^{\mathrm{aA}}$ & $970.83^{\mathrm{bA}}$ & $978.84^{\mathrm{bA}}$ & 15.59 \\
\hline & 7 & $671.25^{\mathrm{bcB}}$ & $713.26^{\mathrm{bB}}$ & $765.31^{\mathrm{abB}}$ & $805.98^{\mathrm{aB}}$ & $707.89^{\mathrm{bB}}$ & $619.35^{\mathrm{cB}}$ & 11.99 \\
\hline & SEM & 27.05 & 45.64 & 38.25 & 41.40 & 37.00 & 48.68 & \\
\hline \multicolumn{2}{|c|}{ Percentage proteolysis } & 20.7 & 30.2 & 25.9 & 26.7 & 27.1 & 36.7 & \\
\hline \multirow[t]{3}{*}{$\alpha_{\mathrm{S} 1}-\mathrm{CN}$} & 1 & $566.74^{\mathrm{A}}$ & $634.59^{\mathrm{A}}$ & $677.69^{A}$ & $722.22^{\mathrm{A}}$ & $657.42^{\mathrm{A}}$ & $638.01^{\mathrm{A}}$ & 25.71 \\
\hline & 7 & $421.99^{\mathrm{B}}$ & $543.86^{\mathrm{B}}$ & $520.9^{\mathrm{B}}$ & $583.18^{\mathrm{B}}$ & $520.58^{\mathrm{B}}$ & $483.11^{\mathrm{B}}$ & 23.98 \\
\hline & SEM & 41.90 & 38.60 & 44.79 & 63.39 & 39.05 & 35.97 & \\
\hline \multicolumn{2}{|c|}{ Percentage proteolysis } & 25.5 & 14.2 & 23.1 & 19.2 & 20.8 & 24.3 & \\
\hline \multirow[t]{3}{*}{$\beta-\mathrm{CN}$} & 1 & $1587.84^{\mathrm{A}}$ & $1624.15^{\mathrm{A}}$ & $1661.73^{\mathrm{A}}$ & $1694.79^{\mathrm{A}}$ & $1654.67^{\mathrm{A}}$ & $1516.92^{\mathrm{A}}$ & 31.05 \\
\hline & 7 & $1089.08^{\mathrm{abB}}$ & $1131.18^{\mathrm{abB}}$ & $1219.80^{\mathrm{aB}}$ & $1114.22^{\mathrm{abB}}$ & $961.97^{\mathrm{bB}}$ & $864.50^{\mathrm{bB}}$ & 32.30 \\
\hline & SEM & 55.95 & 76.76 & 73.09 & 102.34 & 101.59 & 90.66 & \\
\hline \multicolumn{2}{|c|}{ Percentage proteolysis } & 31.4 & 30.4 & 26.6 & 34.2 & 41.9 & 43.0 & \\
\hline \multirow[t]{3}{*}{ para- $\kappa-\mathrm{CN}$} & 1 & $495.04^{\mathrm{bA}}$ & $607.29^{\mathrm{abA}}$ & $696.29^{\mathrm{aA}}$ & $726.21^{\mathrm{aA}}$ & $554.96^{\mathrm{bA}}$ & $599.74^{\mathrm{bA}}$ & 21.12 \\
\hline & 7 & $368.33^{\mathrm{B}}$ & $464.81^{\mathrm{B}}$ & $491.48^{\mathrm{B}}$ & $465.10^{\mathrm{B}}$ & $382.29^{\mathrm{B}}$ & $372.57^{\mathrm{B}}$ & 18.43 \\
\hline & SEM & 26.03 & 33.04 & 43.87 & 51.08 & 37.96 & 41.09 & \\
\hline \multicolumn{2}{|c|}{ Percentage proteolysis } & 25.6 & 23.5 & 29.4 & 35.9 & 31.1 & 37.9 & \\
\hline
\end{tabular}

${ }^{a}$ Values are means; values with different lower case superscript letters within a row and values with different upper case superscript letters within a column differ $(P<0.05)$ for the parameter; SEM, standard error of the mean.

b $\mathrm{CN}$, casein.

c Treatments: RL, raw goat milk with low SCC; RM, raw goat milk with medium SCC; RH, raw goat milk with high SCC; PL, pasteurised goat milk with low SCC; PM, pasteurised goat milk with medium SCC; PH, pasteurised goat milk with high SCC.

milk. Trujillo, Buffa, Casal, Fernández, and Guamis (2002) found lower levels of $\beta \mathrm{CN}$ in cheese made from pasteurised caprine milk compared with that made from raw caprine milk, which was explained by the activation of PG or inactivation of inhibitors of PAs, resulting in a net increase in PL activity in pasteurised milk (Prado, Sombers, Ismail, \& Hayes, 2006).

Increased PL activity in pasteurised milk, which is concomitant with a decrease in PG concentration, is due to the denaturation of the inhibitor(s) of the PAs (Bastian \& Brown, 1996) and the inacti vation of PL inhibitors (Farkye \& Imafidon, 1995). In this study, pasteurisation combined with a high SCC in the milk increased the proteolytic activity in the finished cheese after $7 \mathrm{~d}$ of ripening. Heegaard et al. (1994) reported that polymorphonuclear cells possess PAs, which may explain the accelerated hydrolysis of $\beta \mathrm{CN}$ in pasteurised milk cheese versus raw milk cheese with increased SCC. Generally, PL dominates proteolysis in low SCC milk, with a minor contribution from other enzymes; however, when SCC increases in milk, the relative activity of other enzymes increases above PL activity (Kelly, O'Flaherty, \& Fox, 2006). However, in this experiment, adding somatic cells to the raw caprine milk reduced proteolysis of $\beta \mathrm{CN}$. In contrast, addition of somatic cells to pas teurised caprine milk increased the $\beta \mathrm{CN}$ breakdown. This could be due to high SCC inhibiting enzyme activity in raw milk and slowing hydrolysis of $\beta \mathrm{CN}$, or due to possible inhibitors of somatic cell proteases in raw milk.

Hachana, Kraiem, and Paape (2010) reported that the addition of somatic cell extracts to ultra high temperature, pasteurization (UHT) bovine milk had significant effects on caseins; increasing the concentration of somatic cell proteinase caused a reduction of $\beta \mathrm{CN}$, followed by $\alpha_{\mathrm{S}} \mathrm{CN}$, and lastly $\kappa \mathrm{CN}$. The same findings were reported by Kahina, Moussaoui, Hebia, Laurent, and Le Roux (2005), Le Roux et al. (2003), and Saeman, Verdi, Galton, and Barbano (1988). Le Roux et al. (1995) observed a decrease of $\beta$ $\mathrm{CN}$ and $\alpha_{\mathrm{S}} \mathrm{CN}$ when SCC exceeded 250,000 cells $\mathrm{mL}^{-1}$ in bovine raw milk, but that the level of $\kappa \mathrm{CN}$ was not significantly affected. According to Verdi and Barbano (1991), $\kappa \mathrm{CN}$ is the casein most resistant to proteolysis by somatic cell proteinases. In this study, para $\kappa \mathrm{CN}$, derived from the cleavage of $\kappa \mathrm{CN}$, was broken down during the first week of ripening. No differences were found among the cheese groups at the end of the experiment, but a higher percentage proteolysis was found in pasteurised milk cheese than in raw milk cheeses, similarly to breakdown of $\beta \mathrm{CN}$.

Cathepsin D is ostensibly a lysosomal enzyme (Larsen, Benfeldt, Rasmussen, \& Petersen, 1996), and its level in correlated significantly with SCC (O'Driscoll, Rattray, McSweeney, \& Kelly, 1999). Kaminogawa, Yamauchi, Miyazawa, and Koga (1980) and McSweeney, Fox, and Olson (1995) showed that cathepsin D partially purified from milk hydrolysed $\alpha_{\mathrm{S} 1} \mathrm{CN}$ to a peptide with the same molecular mass or electrophoretic mobility as $\alpha_{\mathrm{S} 1} \mathrm{CN}$ (f24-199), which is one of the primary peptides produced by chymosin. These reports could explain the higher rate of proteolysis of $\alpha_{\mathrm{S} 1} \mathrm{CN}$ in cheeses as somatic cells were added.

Somatic cells also contain several other proteinases (cathepsins B, L and G, and elastase) that have not been studied in detail (Kelly \& McSweeney, 2003). From an enzymatic viewpoint, the different behaviours of somatic cells in raw or pasteurised goat milk cheese needs detailed studies.

\section{Conclusions}

Lipolysis in cheese was clearly dependent on somatic cell counts, which may have important consequences for cheese flavour. On the other hand, the effect of somatic cells on proteolysis is specific for caseins and, in addition, the proteolytic effects of somatic cells on main caseins in cheese are different if cheeses are made with raw or pasteurised milk. This study has shown that the effects of somatic cells on cheese ripening depend on the pretreatment of milk. The use of milk with high SCC will result in a different cheese quality than those made with low SCC.

\section{References}

Albenzio, M., Caroprese, M., Santillo, A., Marino, R., Muscio, A., \& Sevi, A. (2005) Proteolytic patterns and plasmin activity in ewe milk as affected by somatic cell count and stage of lactation. Journal of Dairy Science, 72, 8692.

Álvarez, S., Fresno, M., Méndez, P., Castro, N., Fernández, J. R., \& Sanz Sampelayo, M. R. (2007). Alternatives for improving physical, chemical, and sensory characteristics of goat cheeses: the use of arid-land forages in the diet. Journal of Dairy Science, 90, 21812188.

Azzara, C. D., \& Dimick, P. S. (1985). Lipolytic enzymes activity of macrophages in bovine mammary gland secretions. Journal of Dairy Science, 68, 18041812. 
Bastian, E. D., \& Brown, R. J. (1996). Plasmin in milk and dairy products: an update. International Dairy Journal, 6, 435457.

Buchin, S., Delague, V., Duboz, G., Berdague, J. L., Beuvier, E., Pochet, S., et al. (1998) Influence of pasteurisation and fat composition of milk on the volatile compounds and flavor characteristics of a semi-hard cheese. Journal of Dairy Science, 81, 30973108.

Caroprese, M., Marzano, A., Schena, L., Marino, R., Santillo, A., \& Albenzio, M. (2007). Contribution of macrophages to proteolysis and plasmin activity in ewe bulk milk. Journal of Dairy Science, 90, 27672772.

Chen, S. X., Wang, J. Z., Van Kessel, J. S., Ren, F. Z., \& Zeng, S. S. (2010). Effect of somatic cell count in goat milk on yield, sensory quality, and fatty acid profile of semisoft cheese. Journal of Dairy Science, 93, 13451354.

Chilliard, Y., Selselet-Attou, G., Bas, P., \& Morand-Ferh, P. (1984). Characteristics of lipolytic system in goat milk. Journal of Dairy Science, 67, 22162223.

Collins, Y. F., McSweeney, P. L. H., \& Wilkinson, M. G. (2003). Lipolysis and free fatty acid catabolism in cheese: review of current knowledge. International Dairy Journal, 13, 841866.

Council Directive 92/46/ECC (June 16, 1992) Official Journal. L 268, 14/09/1992, 131.

Dulin, A. M., Paape, M. J., Schultze, W. D., \& Weinland, B. T. (1983). Effect of parity, stage of lactation, and intramammary infection on concentration of somatic cells and cytoplasmic particles in goat milk. Journal of Dairy Science, 66, 24262433.

Erdem, H., Atasever, S., \& Kul, E. (2010). Relationships of milk ability traits to udder characteristics, milk yield and somatic cell count in Jersey cows. Journal of Applied Animal Research, 37, 4347.

FAOSTAT. (2012). http://faostat.fao.org/site/569/DesktopDefault.aspx?PageID 569\# Accessed 10.10.12.

Farkye, N. Y., \& Imafidon, G. I. (1995). Thermal denaturation of indigenous milk enzymes. In Special issue 9501, international dairy federation, heat-induced changes in milk (pp. 331 348). Brussels, Belgium: International Dairy Federation.

Fernández, C., Rodriguez-Alcala, L. M., Abilleira, E., de la Fuente, J. M., \& Fontecha, J. (2009). Influence of betaine on milk yield and fatty acid composition in lactating dairy goats. Journal of Applied Animal Research, 36, 8992.

Fox, P. F. (1993). Cheese: Chemistry, physics and microbiology. London, UK: Chapman and Hall.

Fox, P. F., \& McSweeney, P. L. H. (1996). Proteolysis in cheese during ripening. Food Reviews International, 12, 457509.

Fresno, M., Rodríguez, A., Escudero, A., González, R., Calero, P., Menéndez, S., et al. (2008). ¿Es posible elaborar quesos de leche cruda sin riesgos sanitarios? Ejemplo de los quesos Majoreros y Palmeros. In R. D. Martínez (Ed.), Memorias IX Simposio Iberoamericano sobre la conservación y utilización de recursos zoogenéticos (pp. 393 395), Mar de la Plata, Argentina.

Gaya, P., Medina, M., Rodriguez-Marin, M. A., \& Nuñez, M. (1990). Accelerated ripening of ewe's milk Manchego cheese: the effect of elevated ripening temperatures. Journal of Dairy Science, 73, 2632.

Grappin, R., \& Beuvier, E. (1997). Possible implications of milk pasteurisation on the manufacture and sensory quality of ripened cheese. International Dairy Journal, 7, 751761.

Hachana, Y., \& Kraiem, K. (2009). Proteolysis and storage stability of ultra high temperature processed milk as influenced by somatic cell count and bacterial count. Journal of Applied Animal Research, 36, 6570.

Hachana, Y., Kraiem, K., \& Paape, M. J. (2010). Effect of plasmin, milk somatic cells and psychrotrophic bacteria on casein fractions of ultra high temperature treated milk. Food Science and Technology Research, 16, 7986.

Haenlein, G. F. W., \& Hinckley, L. S. (1995). Goat milk somatic cell count situation in USA. International Journal of Animal Science, 10, 305310.

Harmon, R. J. (1994). Physiology of mastitis and factors affecting somatic cell count. Journal of Dairy Science, 77, 21032112.

Heegaard, C. W., Christensen, T., Rasmussen, M. D., Benfeldt, C., Jensen, N. E., Sejrsen, K., et al. (1994). Plasminogen activators in bovine milk during mastitis, an inflammatory disease. Fibrinolysis, 8, 2230.

Henry, G., Mollé, D., Morgan, F., Fauquant, J., \& Bouhallab, S. (2002). Heat induced covalent complex between casein micelles and $\beta$-lactoglobulin from goats milk: identification of an involved disulfide bond. Journal of Agricultural and Food Chemistry, 50, 185191.

Huijps, K., Lam, T. J., \& Hogeveen, H. (2008). Costs of mastitis: facts and perception. Journal of Dairy Research, 75, 113120.

Jaeggi, J. J., Govindasamy-Lucey, S., Berger, Y. M., \& Johnson, M. E. (2003). Hard ewe's milk cheese manufactures from milk of three different groups of somatic cell counts. Journal of Dairy Science, 86, 30823089.

Jaubert, G., Bodin, J. P., \& Jaubert, A. (1996). Flavour of goat farm bulk milk. In Proceedings of the sixth international conference on goats (pp. 66 69), Beijing, China.

Kahina, H., Moussaoui, F., Hebia, I., Laurent, F., \& Le Roux, Y. (2005). E. coli proteolytic activity in milk and casein breakdown. Reproduction Nutrition Development, 45 485496.

Kaminogawa, S., Yamauchi, K., Miyazawa, S., \& Koga, Y. (1980). Degradation of casein components by acid protease of bovine milk. Journal of Dairy Science, 63, 701704.

Kelly, A. L., \& Fox, P. F. (2006). Indigenous enzymes in milk: a synopsis of future research requirements. International Dairy Journal, 16, 707715.

Kelly, A. L., \& McSweeney, P. L. H. (2003). Indigenous proteolytic enzymes in milk. In P. F. Fox, \& P. L. H. McSweeney (Eds.), Advanced dairy chemistry I (proteins) (pp. 495 544). New York, NY, USA: Kluwer Academic Plenum Publishers.
Kelly, A. L., O'Flaherty, F., \& Fox, P. F. (2006). Indigenous proteolytic enzymes in milk: a brief overview of the present state of knowledge. International Dairy Journal, $16,563572$.

Laemmli, U. K. (1970). Cleavage of structural proteins during the assembly of the head of bacteriophage T4. Nature, 227, 680682.

Larsen, L. B., Benfeldt, C., Rasmussen, L. K., \& Petersen, T. E. (1996). Bovine milk procathepsin D and cathepsin D: coagulation and milk protein degradation. Journal of Dairy Science, 63, 119130.

Le Roux, Y., Colin, O., \& Laurent, F. (1995). Proteolysis in samples of quarter milk with varying somatic cell counts. 1. Comparison of some indicators of endogenous proteolysis in milk. Journal of Dairy Science, 78, 12891297.

Le Roux, Y., Laurent, F., \& Moussaoui, F. (2003). Polymorphonuclear proteolytic activity and milk composition change. Veterinary Research, 34, 629645.

Ma, Y., Barbano, D. M., \& Santos, M. (2003). Effect of $\mathrm{CO}_{2}$ addition to raw milk on proteolysis and lipolysis at $4{ }^{\circ} \mathrm{C}$. Journal of Dairy Science, 86, 16161631.

Marino, R., Considine, T., Sevi, A., McSweeney, P. L. H., \& Kelly, A. L. (2005). Contribution of proteolytic activity associated with somatic cells in milk to cheese ripening. International Dairy Journal, 15, 10261033.

McSweeney, P. L. H., Fox, P. F., Lucey, J. A., Jordan, K. N., \& Cogan, T. M. (1993). Contribution of the indigenous microflora to the maturation of Cheddar cheese. International Dairy Journal, 3, 613634.

McSweeney, P. L. H., Fox, P. F., \& Olson, N. F. (1995). Proteolysis of bovine caseins by cathepsin D: preliminary observations and comparison with chymosin. International Dairy Journal, 5, 321336.

Melilli, C., Barbano, D. M., Manenti, M., Lynch, J. M., Carpino, S., \& Licitra, G. (2004) Lipolysis and proteolysis in Ragusano cheese during brine salting at different temperatures. Journal of Dairy Science, 87, 23592374.

Moslehishad, M., \& Ezzatpanah, H. (2010). Transmission electron microscopy study of casein micelle in raw milk with different somatic cell count levels. International Journal of Food Properties, 13, 546552.

Morgan, F., \& Gaborit, P. (2001). The typical flavour of goat milk products: technological aspects. International Journal of Dairy Technology, 54, 3840.

O’Driscoll, B. M., Rattray, F. P., McSweeney, P. L. H., \& Kelly, A. K. (1999). Protease activities in raw milk determined using a synthetic heptapeptide substrate. Journal of Food Science, 64, 606611.

Paape, M. J., Poutrel, B., Contreras, A., Marco, J. C., \& Capuco, A. V. (2001). Milk somatic cells and lactation in small ruminants. Journal of Dairy Science, 84(E. Suppl.), 237244.

Paape, M. J., Wiggans, G. R., Bannerman, D. D., Thomas, D. L., Sanders, A. H. Contreras, A., et al. (2007). Monitoring goat and sheep milk somatic cell counts. Small Ruminant Research, 68, 114125.

Pearse, M. J., Linklater, P. M., Hall, R. J., \& MacKinlay, A. G. (1985). Effect of heat induced interaction between $\beta$-lactoglobulin and $\kappa$-casein on syneresis. Journal of Dairy Research, 52, 159165.

Pirisi, A., Piredda, G., Corona, M., Pes, M., Pintus, S., \& Ledda, A. (2000). Influence of somatic cell count on ewe's milk composition, cheese yield and cheese quality. In Proceedings of sixth great lakes dairy sheep symposium (pp. 47 59), Guelph, ON, Canada.

Politis, I., \& Ng-Kwai-Hang, K. F. (1988). Association between somatic cell count of milk and cheese-yielding capacity. Journal of Dairy Science, 71, 17201727.

Politis, I., White, J. H., O'hare, K., Zavizion, B., Gilmore, J., \& Caler, W. (1994). Distribution of plasminogen activator forms in fraction of goat milk. Journal of Dairy Science, 77, 90029006.

Prado, B. M., Sombers, S. E., Ismail, B., \& Hayes, K. D. (2006). Effect of heat treatment on the activity of inhibitors of plasmin and plasminogen activators in milk. International Dairy Journal, 16, 593599.

Raynal-Ljutovac, K., Gaborit, P., \& Lauret, A. (2005). The relationship between quality criteria of goat milk, its technological properties and the quality of the final products. Small Ruminant Research, 60, 167177.

Raynal-Ljutovac, K., Pirisi, A., de Crémoux, R., \& Gonzalo, C. (2007). Somatic cells of goat and sheep milk: analytical, sanitary, productive and technological aspects. Small Ruminant Research, 68, 126144

Ribeiro, A. C., \& Ribeiro, S. D. A. (2010). Specialty products made from goat milk. Small Ruminant Research, 89, 225233.

Rynne, N. M., Beresford, T. P., Kelly, A. L., \& Guinee, T. P. (2004). Effect of milk pasteurisation temperature and in situ whey protein denaturation on the composition, texture and heat-induce functionality of half-fat Cheddar cheese. International Dairy Journal, 14, 9891001.

Saeman, A. I., Verdi, R. J., Galton, D. M., \& Barbano, D. M. (1988). Effects of mastitis on proteolytic activity in bovine milk. Journal of Dairy Science, 71, 505512.

Sánchez-Macías, D., Fresno, M., Moreno-Indias, I., Castro, N., Morales-delaNuez, A., Álvarez, S., et al. (2010). Physicochemical analysis of full-fat, reduced-fat, and low-fat artisan-style goat cheese. Journal of Dairy Science, 93, 39503956.

Sánchez-Macías, D., Morales-delaNuez, A., Moreno-Indias, I., HernándezCastellano, L. E., Mendoza-Grimón, V., Castro, N., et al. (2011). Lipolysis and proteolysis profiles of fresh artisanal goat cheese made with raw milk with three different fat contents. Journal of Dairy Science, 94, 57865793.

Shakeel-Ur-Rehman, Fox, P. F., McSweeney, P. L. H., Madkor, S., \& Farkye, N. (2001). Alternatives to pilot plant experiments in cheese ripening studies. International Journal of Dairy Technology, 54, 121126.

Shipe, W. F., Senyk, G. F., \& Fountain, K. B. (1980). Modified copper soap solvent extraction method for measuring free fatty acids in milk. Journal of Dairy Science, 63, 193198.

Silakinove, N., Leitner, G., Merin, U., \& Prosser, C. G. (2010). Recent advances in exploiting goat's milk: quality, safety and production aspects. Small Ruminant Research, 89, 110124. 
Trujillo, A. J., Buffa, M., Casal, I., Fernández, P., \& Guamis, B. (2002). Proteolysis in goat cheese made from raw, pasteurised or pressure-treated milk. Innovative Food Science and Emerging Technologies, 3, 295307.

Tunick, M. H., Malin, E. L., Smith, P. W., \& Hilsinger, V. H. (1995). Effects of skim milk homogenization on proteolysis and rheology of Mozzarella cheese. Internationa Dairy Journal, 5, 483491.

Tziboula-Clarke, A. (2003). Goat milk. In J. W. Fuquay, \& P. F. Fox (Eds.), Encyclopedia of dairy sciences (pp. 1270 1279). San Diego, CA, USA: Academic Press. van Vliet, T., \& Walstra, P. (1994). Water in casein gels; how to get it out or keep it in Journal of Food Engineering, 22, 7588.

Verdi, R. J., \& Barbano, D. M. (1991). Properties of proteases from milk somatic cells and blood leucocytes. Journal of Dairy Science, 74, 20772081.

Vianna, C. P. B., Mazal, G., Santos, M. V., Bolini, H. M. A., \& Gigante, M. L. (2008) Microbial and sensory changes throughout the ripening of Prato cheese made from milk with different levels of somatic cells. Journal of Dairy Science, 91, 17431750. 